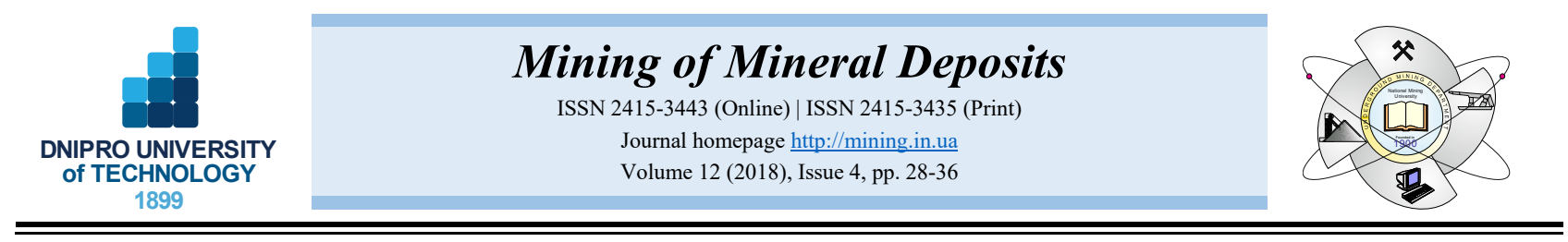

UDC 622.28.042/.044:624.01

https://doi.org/10.15407/mining12.04.028

\title{
CONTROLLING STRESS STATE OF A HOISTING SHAFT FRAME IN THE CONTEXT OF SPECIFIC FREEZING PROCESS
}

\author{
O. Tiutkin ${ }^{1 *}$, V. Petrenko ${ }^{1}$, N. Petrosian ${ }^{1}$, V. Miroshnyk ${ }^{1}$, A. Alkhdour ${ }^{2}$ \\ ${ }^{I}$ Dnipropetrovsk National University of Railway Transport named after Academician V. Lazaryan, Dnipro, Ukraine \\ ${ }^{2}$ Al-Balqa'Applied University, Al-Salt, Jordan \\ *Corresponding author: e-mail alexeytutkin@gmail.com,tel.+30563731553
}

\begin{abstract}
Purpose is to obtain regularities of a stress state of such multilayer system as neighbourhood rock mass - frozen soil hoisting shaft frame in the process of numerical analysis to control a frame state with the selection of efficient parameters; thickness depending upon a specific frozen process specifically.

Methods. Numerical analysis on the basis of a finite-element method has been implemented relying upon Pro Complex Structure CAD for Windows (SCAD) which made it possible to obtain stress state of a hoisting shaft frame and its interaction with ice-soil blocking as well as with neighbourhood rock mass soil.

Findings. Hoisting shaft model has been developed. The model is based upon actual geometry and results of laboratory studies. Three blocking types (i.e. reinforced-concrete blocks, gray cast-iron tubbings, and modified gray castiron tubbings) and two soil types (i.e. sand and clayish soil at $+8^{\circ} \mathrm{C}$ temperature) in terms of different freezing temperatures (i.e. $\left(-2,-6\right.$ and $-10^{\circ} \mathrm{C}$ ) were analyzed numerically with the use of the SCAD. Results of the research have helped identify dependences concerning formation of a stress state of the multilayer neighbourhood rock mass frozen soil - hoisting shaft frame system while varying properties of the listed types of a frame, neighbourhood rock mass, and ice-soil blocking. Regularities of the stressed state components deepening upon the frozen soil elasticity modulus, corresponding to its certain temperature, and elasticity modulus of a hoisting shaft frame have been obtained. The regularities connect changes in the stress of a hoisting shaft blocking in the context of specific freezing process.
\end{abstract}

Originality. The obtained dependences of the stressed state of a hoisting shaft frame on the soil elasticity modulus and the material are composite spatial surfaces reflecting representatively the stressed state of such multilayer systems as neighbourhood rock mass - frozen soil - hoisting shaft frame.

Practical implications. The regularities of the stressed state, determined for such multilayer systems as neighbourhood rock mass - frozen soil - hoisting shaft frame, make it possible to control stress components selecting rational geometry of a frame and its material or temperature cycle to freeze soils while applying the specific method.

Keywords: hoisting shaft, stressed state, neighbourhood rock mass - frozen soil - hoisting shaft frame system, soil freezing, ice-soil blocking, numerical analysis

\section{INTRODUCTION}

Ukrainian cities as Kyiv, Kharkiv, and Dnipro involves, first of all, the widest field of operations. For all the subways, a procedure is as follows: underground operations to construct station tunnels and deep running tunnels. Specific character of the underground method is that surface opening is the only possible with the use of additional inclined and vertical mine workings (Petrenko, Petrenko, \& Tyut'kin, 2005). Then, after underground objects are constructed, the mine workings can be applied as escalators (i.e. inclined) and ventilation openings (i.e. vertical ones).
Vertical openings, making it possible to start operations at an underground level, are called hoisting shafts. Several approaches to support them are available; they depend upon the character of geotechnical and hydrogeological situation. To support hoisting shafts for deep-laid lines, Dnipro subway uses reinforced concrete blockings consisting of interlocking piles. Such piles are made on the basis of augered technique making it possible to support hoisting shafts which depth is $25-30 \mathrm{~m}$. However, the technique is not mature one in Ukraine involving its scientific substantiation. Artificial soil freezing is the most popular method to block a hoisting shaft structure (Dorman, 1981; Harris, 1995; Andersland \& Ladanyi, 2003).

(C) 2018. O. Tiutkin, V. Petrenko, N. Petrosian, V. Miroshnyk, A. Alkhdour. Published by the Dnipro University of Technology on behalf of Mining of Mineral Deposits. This is an Open Access article distributed under the terms of the Creative Commons Attribution License (http://creativecommons.org/licenses/by/4.0/), which permits unrestricted reuse, distribution, and reproduction in any medium, provided the original work is properly cited. 
The specific method to support both hardness and stability of rock mass in the neighborhood of a hoisting shaft is one of the efficient technique to strengthen soil in the process of subway construction under complicated geotechnical conditions (Dorman, 1981; Donohoe, Maishman, \& Schmall, 1998). It is also used to drive inclined escalator tunnels, station tunnels, and running subway tunnels, various cavations, entrances, underground cells, retaining walls etc.

Artificial soil freezing helps develop solid circularsection blocking required to prevent ground water or water-saturated unstable soil from their entering a mine working under construction (Hohmann, 1997; Alzoubi, Sasmito, Madiseh, \& Hassani, 2017). Such a blocking takes up pressure of soil, surrounding the mine working, as well as hydrostatic pressure of ground water.

Recently, a number of studies have been carried out to determine correspondence between the strength and thickness of hoisting shaft, and active load (Dorman, 1981; Chan 1985; Falter, 1990; Falter, 1996; Coulthard, 1999). It has been proved that hoisting shaft thickness may be reduced without loss of its stability and strength to be a reason for diminution in total construction value.

It should be noted that getting an idea of structural behaviuor of supports of vertical mine workings is controversial. That can be explained by the fact that rock pressure in the neighbourhood of mine workings is formed depending upon stress redistribution in the process of their construction, geotechnical situation with neighbourhood rock mass and mining conditions. Exceptional variety of both natural and industrial parameters stipulates extra complexity as for the prognosis of stress-strain state of vertical mine workings and inclined ones. Due to it, no unified ideology concerning nature and interaction mechanism between supports of such mine workings and rock mass has been developed; moreover, basic parameters of such an interaction are not available.

Studies concerning interaction between rock mass and supports of both vertical and inclined mine workings are carried out as follows: full-scale measurements as an initial step, then laboratory experiments (modeling), and analytical calculations as a final stage. Each of the stage has its own pluses and minuses; it goes without saying, integrated approach is the most respectable one since it involves the use of all of the tendencies. However, in view of some or other reasons, it is not always possible. If so, during certain stage, studies implement one of the tendencies.

Changes in characteristics of water-saturated and subsequently frozen soft soil or stratified soil of neighbourhood rock mass are complicated problems in the process of a stress state formation for vertical mine workings while applying specific freezing method. The problems can be solved when a set of calculations is performed as a part of numerical analysis of a multilayer neighbourhood rock mass - frozen soil - hoisting shaft frame system (Dorman, 1981; Yang, Yang, Han, Zhang, \& Bo, 2012; Yang, Yang, \& Bo, 2013) inclusive of temperature running value (Pimentel, Sres, \& Anagnostou, 2007).

Analysis of such calculation techniques as finiteelement method, boundary-element method and others shows that a finite-element method is the most advanta- geous to perform numerous calculations with running system parameters. The method has been used effectively by a number of specialized calculation systems making it possible to simulate geometry of a multilayer neighbourhood rock mass - frozen soil - hoisting shaft frame system while giving it characteristics of real soil.

Idea of the research is to control stress state of a hoisting shaft in the context of specific freezing method. Such a control is implemented by means of studies of results of numerical analysis of different states in the process of soil freezing and obtaining regularities of the stress state in the context of changes in their characteristics. While varying stress state of the frozen rock mass, that makes it possible to control stress state of a frame, thus selecting its rational geometry, its thickness specifically. Objective of the research is to obtain regularities of stress state of a multilayer neighbourhood rock mass frozen soil - hoisting shaft frame system.

\section{METHODOLOGY}

A number of series of numerical analysis concerning a multilayer neighbourhood rock mass - frozen soil hoisting shaft frame system were performed on the basis of finite-element method. Hoisting shaft was calculated to determine ice-soil blocking effect and to identify its importance in the process of formation of stress state of the shaft as well as rock mass while freezing soil neighbouring the soil around the hoisting shaft frame. To do that, shaft model was developed involving the frame neighbourhoodd rock mass interaction.

The model of a hoisting shaft relies upon real geometry, results of laboratory studies, and the use of Pro Complex Structure CAD for Windows, version 11.5 (SCAD) (Karpilovskiy, Kriksunov, \& Perel'muter, 2000).

Stage one involves the development of a flat prototype (Fig. 1) (Borshchevskiy, Petrenko, Tyut'kin, Antonov, \& Pleshko, 2006). A form of the plate finite elements should resemble square since the form favours the most adequate calculations of the scheme by means of SCAD.

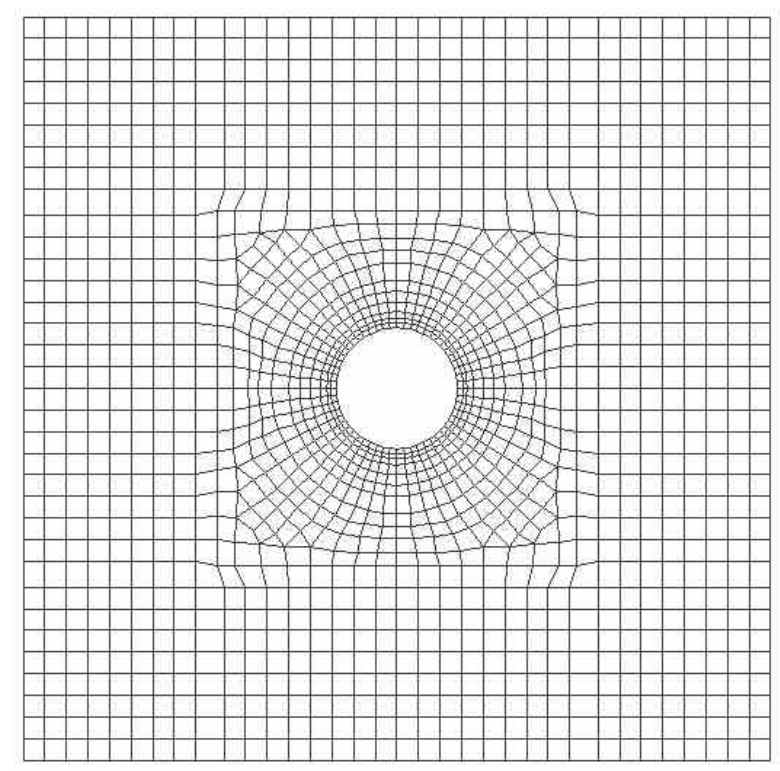

Figure 1. Flat prototype of CE-model of a shaft 
Then, vertical axis coping was applied to develop a spatial model (Fig. 2). CE-model is based upon solid finite elements (133812 nodes, and 125120 finite elements); it simulates maximally the hoist structure neighbourhood rock mass interaction (Levit, Tyut'kin, \& Borshchevskiy, 2007). The model simulates hoisting shaft with $40 \mathrm{~m}$ depth, and $5.1 \mathrm{~m}$ internal diameter; frame thickness is $0.5 \mathrm{~m}$, ice-soil blocking width is $2.32 \mathrm{~m}$, and average width of neighbourhood soil mass is $10.6 \mathrm{~m}$.

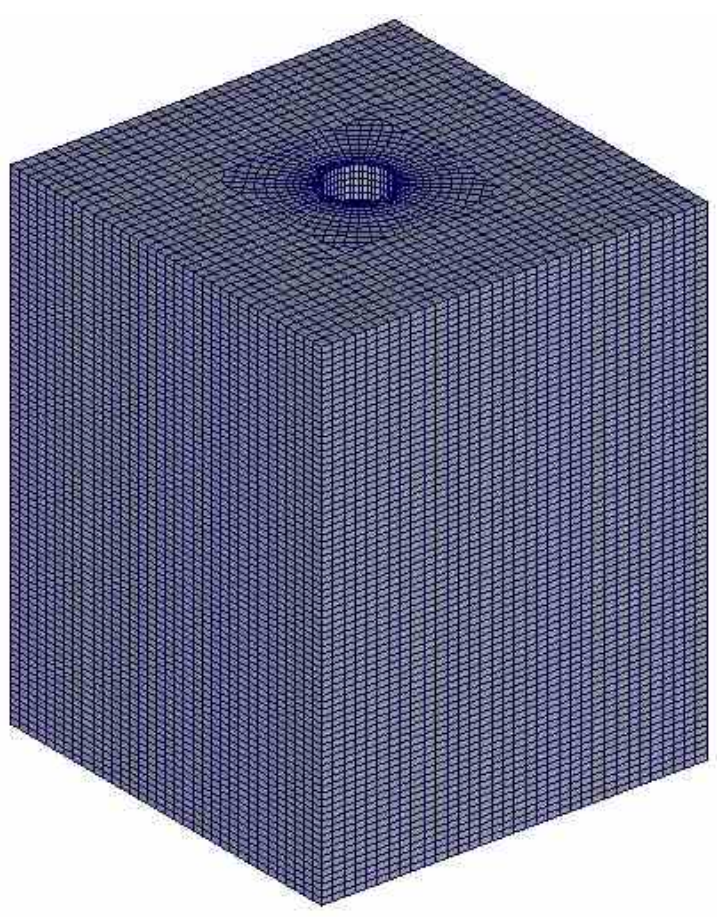

Figure 2. Spatial CE- model of a hoisting shaft

After spatial model was developed, it obtained proper strain characteristics (i.e. elasticity modulus, and Poisson ratio); moreover, they were scheduled separately for the soil, ice-soil blocking, and frame material. In the context of numerical analysis, several series of calculations, concerning the model of a hoisting shaft, were performed. Three frame types (i.e. reinforced-concrete blocks, grey cast iron tubings, and modified cast iron ones); two soil types (i.e. sand and clayish soil at $+8^{\circ} \mathrm{C}$ ) were studied in terms of various freezing temperatures (i.e. $-2,-6$ and $-10^{\circ} \mathrm{C}$ ). Below you can find strain characteristics, simulated within the CE-models.

Strain characteristics of a frame are:

- reinforced-concrete blocks of B30 concrete: reduced elasticity modulus is $E=2.03 \cdot 10^{4} \mathrm{MPa}$; Poisson ratio is $\mu=0.3$; and reduced specific weight is $\gamma=25 \mathrm{kN} / \mathrm{m}^{3}$;

- gray cast iron tubings: reduced elasticity modulus is $E=1.95 \cdot 10^{5} \mathrm{MPa}$; Poisson ratio is $\mu=0.3$; and specific weight is $\gamma=7.2 \mathrm{kN} / \mathrm{m}^{3}$;

- modified cast iron tubings: reduced elasticity modulus is $E=2.93 \cdot 10^{5} \mathrm{MPa}$; Poisson ratio is $\mu=0.3$; and specific weight is $\gamma=7.2 \mathrm{kN} / \mathrm{m}^{3}$.

Strain characteristics of a neighbourhood rock mass are:

- medium coarse sand: soil temperature is $t=+8^{\circ} \mathrm{C}$; porosity ratio is $e=0.45$; elasticity modulus is $E=40 \mathrm{MPa}$; Poisson ratio is $\mu=0.3$; and specific weight is $\gamma=20 \mathrm{kN} / \mathrm{m}^{3}$;
- clayish soil: ground temperature is $t=+8^{\circ} \mathrm{C}$; plasticity number is $0.25<I_{L}<0.5$; porosity ratio is $e=0.5$; elasticity modulus is $E=25 \mathrm{MPa}$; Poisson ratio is $\mu=0.3$; and specific weight is $\gamma=20 \mathrm{kN} / \mathrm{m}^{3}$.

Strain characteristics of ice-soil blocking are:

- medium coarse sand: soil temperature is $t=-2^{\circ} \mathrm{C}$; porosity ratio is $e=0.45$; elasticity modulus is $E=53 \mathrm{MPa}$; Poisson ratio is $\mu=0.3$; and specific weight is $\gamma=20 \mathrm{kN} / \mathrm{m}^{3}$;

- medium coarse sand: soil temperature is $t=-6^{\circ} \mathrm{C}$; porosity ratio is $e=0.45$; elasticity modulus is $E=138 \mathrm{MPa}$; Poisson ratio is $\mu=0.3$; and specific weight is $\gamma=20 \mathrm{kN} / \mathrm{m}^{3}$;

- medium coarse sand: soil temperature is $t=-10^{\circ} \mathrm{C}$; porosity ratio is $e=0.45$; elasticity modulus is $E=225 \mathrm{MPa}$; Poisson ratio is $\mu=0.3$; and specific weight is $\gamma=20 \mathrm{kN} / \mathrm{m}^{3}$;

- clayish soil: ground temperature is $t=-2^{\circ} \mathrm{C}$, plasticity number is $0.25<I_{L}<0.5$, porosity ratio is $e=0.5$, elasticity modulus is $E=30 \mathrm{MPa}$; Poisson ratio is $\mu=0.3$, and specific weight is $\gamma=20 \mathrm{kN} / \mathrm{m}^{3}$;

- clayish soil: ground temperature is $t=-6^{\circ} \mathrm{C}$, plasticity number is $0.25<I_{L}<0.5$, porosity ratio is $e=0.5$, elasticity modulus is $E=35 \mathrm{MPa}$; Poisson ratio is $\mu=0.3$, and specific weight is $\gamma=20 \mathrm{kN} / \mathrm{m}^{3}$;

- clayish soil: ground temperature is $t=-10^{\circ} \mathrm{C}$, plasticity number is $0.25<I_{L}<0.5$, porosity ratio is $e=0.5$, elasticity modulus is $E=43 \mathrm{MPa}$; Poisson ratio is $\mu=0.3$, and specific weight is $\gamma=20 \mathrm{kN} / \mathrm{m}^{3}$.

It has been known that elasticity modulus $E(\mathrm{MPa})$ is determined under cyclic loading of frozen soil samples; the procedure is repeated until the stable elastic deformation has been determined. Analysis considers average values which number should not be less than five separate specifications. Research shows that it is tens or even hundreds times more than elasticity modulus of unfrozen soil (i.e. $E \approx 300-30000 \mathrm{MPa}$ ). Its value depends upon a number of such factors as frozen soil composition, ice content, a value of negative temperature, and environmental pressure.

Three types of frozen soils were used for the research:

- frozen sand (with following fraction particles: $>0.25 \mathrm{~mm}$ fraction $-93.0 \% ; 0.25-0.05 \mathrm{~mm}$ fraction $5.6 \% ; 0.05 \mathrm{~mm}$ fraction $-1.4 \%$; and such average total moisture as $W_{c}=17-19 \%$ );

- frozen dusty soil (amount of $>0.05 \mathrm{~mm}$ fraction $35.6 \%$; $<0.005 \mathrm{~mm}-9.2 \%$; and $W_{c}=26-29 \%$;

- frozen clay (amount of $<0.005 \mathrm{~mm}$ fraction is more than $50 \%$ when $W_{c}=46-56 \%$ ) as well as the samples of permanently frozen disperse soil of undisturbed structure.

Frozen sand has the maximum modulus of normal elasticity (in the context of the research, a value of normal elasticity modulus was obtained from $82 \mathrm{MPa}$ at $0=0.2^{\circ} \mathrm{C}$ up to $225 \mathrm{MPa}$ at $0=-10.2^{\circ} \mathrm{C}$; frozen clay had the least modulus, i.e. from $68 \mathrm{MPa}$ at $0=-1.2^{\circ} \mathrm{C}$ up to $278 \mathrm{MPa}$ at $0=-8.4^{\circ} \mathrm{C}$ ); values of normal elasticity modulus of dusty clayish soil and sandy soil are average ones.

According to the results of qualitative analysis and quantitative analysis of the developed models it is required to:

- determine regularities of changes in stress-strain state of a hoisting shaft frame during freezing-unfreezing cycle; 
- evaluate the efficiency of the frame in terms of its interaction with neighbourhood rock mass and ice-soil blocking depending upon the types of the blocking and soil;

- develop regularities to simplify significantly calculations of the hoisting shaft bearing capability while developing real projects;

- identify dependences of stress state components of a hoisting shaft frame upon soil elasticity modulus and material which will reflect representatively stress state of a multilayer neighbourhood rock mass - frozen soil hoisting shaft frame system.

\section{RESULTS AND DISCUSSION}

Consider figures of isolines and isofields of SCAD CE-models while performing qualitative analysis of the obtained data basing upon the results of numerical calculations (Figure 3 demonstrates representative distribution pattern only; the paper omits other numerical patterns to save room).

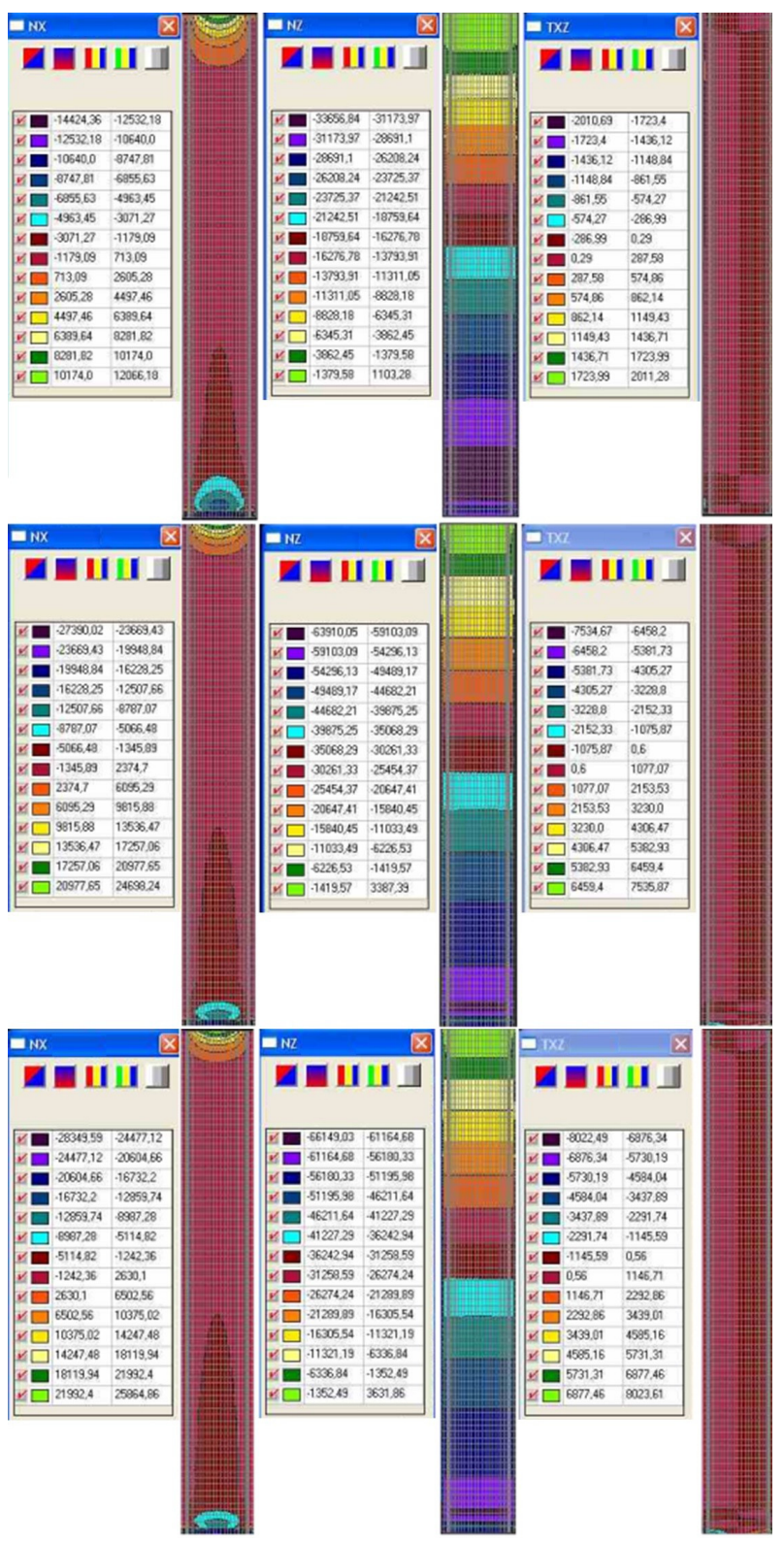

Figure 3. Characteristic pattern of isolines and isofields of a stress state within sand at $-2^{\circ} \mathrm{C}$ temperature
Within a frame, points with maximum stress values (i.e. $N_{x}$ - normal stresses on a horizontal axis; $N_{z}-$ normal stresses on a vertical axis; and $T_{x z}-$ shear stresses within $X Z$ plane) have been selected for the numerical analysis.

To obtain regularities of a stress state of the multilayer neighbourhood rock mass - frozen soil - hoisting shaft frame system, graphs of stress dependence upon elasticity modulus have been constructed and approximated during the numerical analysis to control stress state of a frame. Moreover, the obtained data were approximated.

As for the sand, the approximated regularities for components of a stress state are 3rd-order compound polynomials (Figs. $4-6$ ).

Hereinafter, the paper will demonstrate results for sand and sandy clay since the soils occur around the planned shaft next to Lvivska Brama idle station of Kyiv subway.

The regularity graphs were constructed on the points; according to the approximation of the graphs, values of their functions were obtained.

If the frame is made of reinforced concrete blocks, then:

$-N_{x}$ dependence of sand $E$ is $y=1448.9 x^{-1.2158}$;

$-N_{z}$ dependence of sand $E$ is $y=1919.2 x^{-1.0663}$;

$-T_{x z}$ dependence of sand $E$ is $y=229.51 x^{-1.0491}$.

If the frame is made of gray sand tubings, then:

$-N_{x}$ dependence of sand $E$ is $y=0.0003 x^{2}-$ $-0.1345 x+31.219$

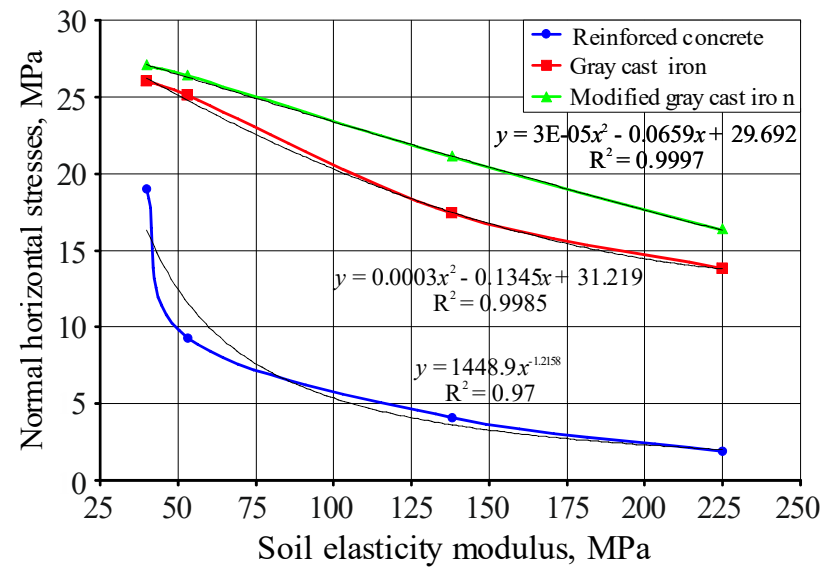

Figure 4. Graph of $N_{x}$ regularities depending upon sand elasticity modulus for the three frame types

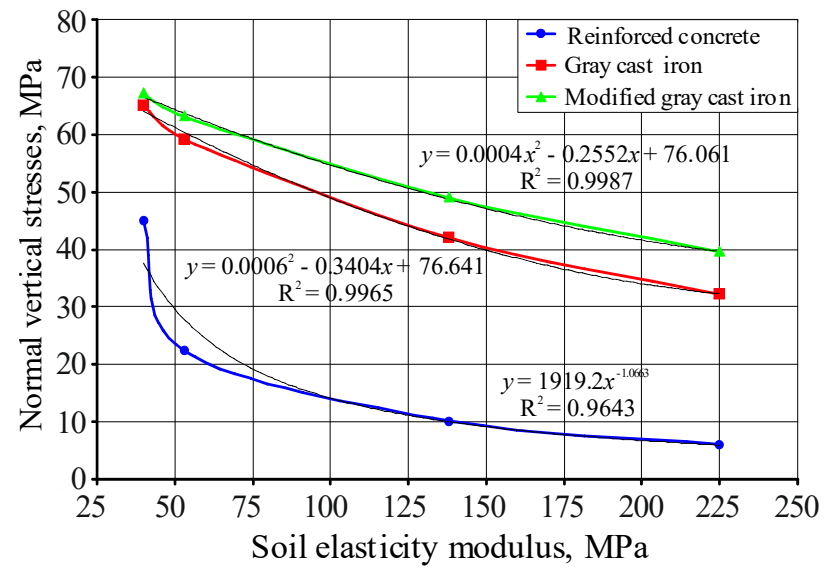

Figure 5. Graph of $\mathrm{Nz}$ regularities depending upon sand elasticity for the three frame types 


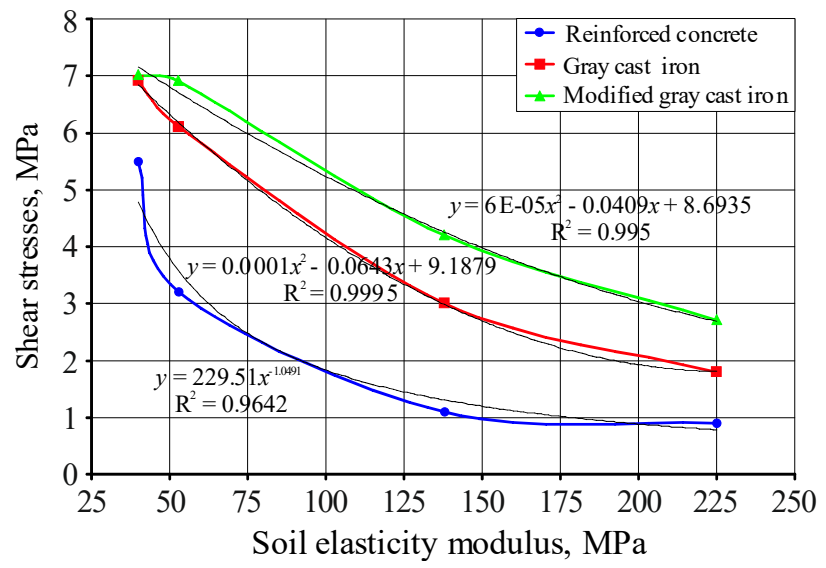

Figure 6. Graph of $T_{x z}$ regularities depending upon sand elasticity for the three frame types

$-N_{z}$ dependence of sand $E$ is $y=0.0006 x^{2}-$ $-0.3404 x+76.641$

$-T_{x z}$ dependence of sand $E$ is $y=0.0001 x^{2}-$ $-0.0643 x+9.1879$.

If the frame is made of the modified gray reinforced concrete, then:

$-N_{x}$ dependence of sand $E$ is $y=3 E-0.5 x^{2}-$ $-0.0659 x+29.692$

$-N_{z}$ dependence of sand $E$ is $y=0.0004 x^{2}-$ $-0.2552 x+76.061$

$-T_{x z}$ dependence of sand $E$ is $y=6 E-0.5 x^{2}-$ $-0.0409 x+8.6935$.

Standard error of the graphs is $R^{2}$ being close to 1 confirming high-grade approximation; however, it does not mean that the obtained functions are perfect since they were constructed on four points. Nevertheless, such accuracy is acceptable taking into account the research level.

Analyze the graphs qualitatively.

When sandy soil freezes down to $-10^{\circ} \mathrm{C}$, maximum stresses within reinforced concrete frame are as follows: $N_{x}=1.9 \mathrm{MPa}$ if normal stresses along $X$ axis (horizontal); $N_{z}=6.1 \mathrm{MPa}$ if normal stresses along $Z$ axis (vertical); and $T_{x z}=0.9 \mathrm{MPa}$ if shear stresses within $X Z$ plane.

When sandy soil freezes down to $-10^{\circ} \mathrm{C}$, maximum stresses within gray cast iron tubing frame are as follows: $N_{x}=13.8 \mathrm{MPa}$ if normal stresses along $X$ axis (horizontal); $N_{z}=32.2 \mathrm{MPa}$ if normal stresses along $Z$ axis (vertical); and $T_{x z}=1.8 \mathrm{MPa}$ if shear stresses within $X Z$ plane.

When sandy soil freezes down to $-10^{\circ} \mathrm{C}$, maximum stresses within the modified gray cast iron tubing frame are as follows: $N_{x}=16.3 \mathrm{MPa}$ if normal stresses along $X$ axis (horizontal); $N_{z}=39.6 \mathrm{MPa}$ if normal stresses along $Z$ axis (vertical); and $T_{x z}=2.7 \mathrm{MPa}$ if shear stresses within $X Z$ plane.

In the case of sandy clay, the approximated regularities for a stress state of neighbourhood soil are $3^{\text {rd }}$-order polynomials as well (Figs. $7-9$ ).

The graphs of regularities were also constructed on points; their approximation results were used to obtain values of their functions.

If the frame is made of reinforced concrete blocks, then:

$-N_{x}$ dependence of sandy clay $E$ is $y=0.0337 x^{2}-$ $-2.6222 x+65.695$

$-N_{z}$ dependence of sandy clay $E$ is $y=0.0714 x^{2}-$ $-5.7423 x+148.93$

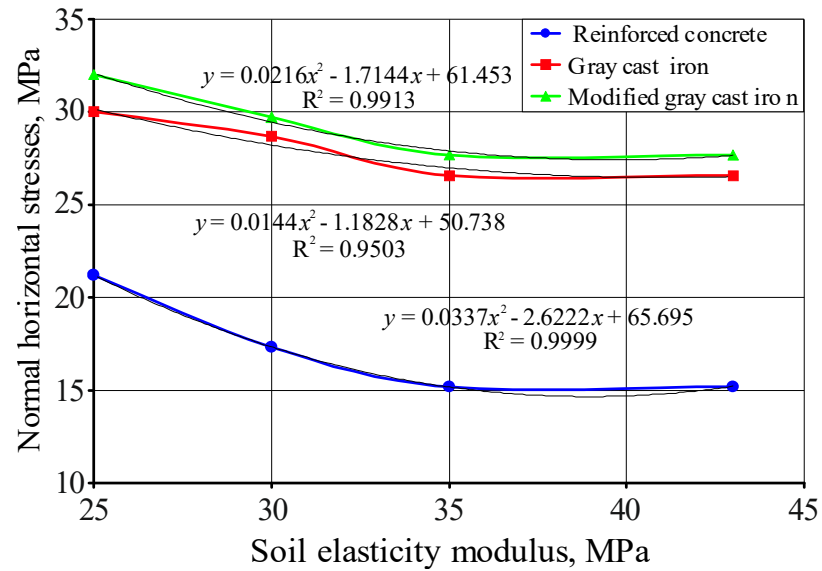

Figure 7. Graph of $N_{x}$ regularities depending upon sandy soil elasticity modulus for the three frame types

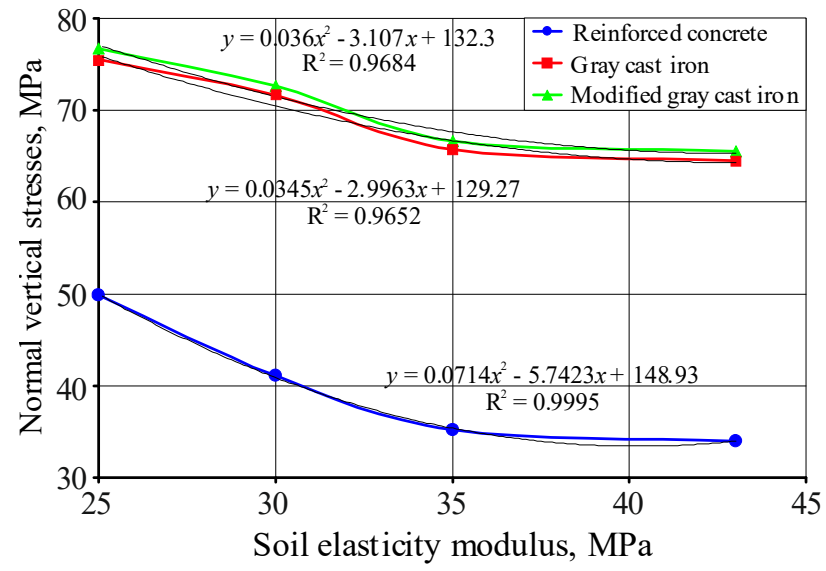

Figure 8. Graph of $N_{z}$ regularities depending upon sandy soil elasticity modulus for the three frame types

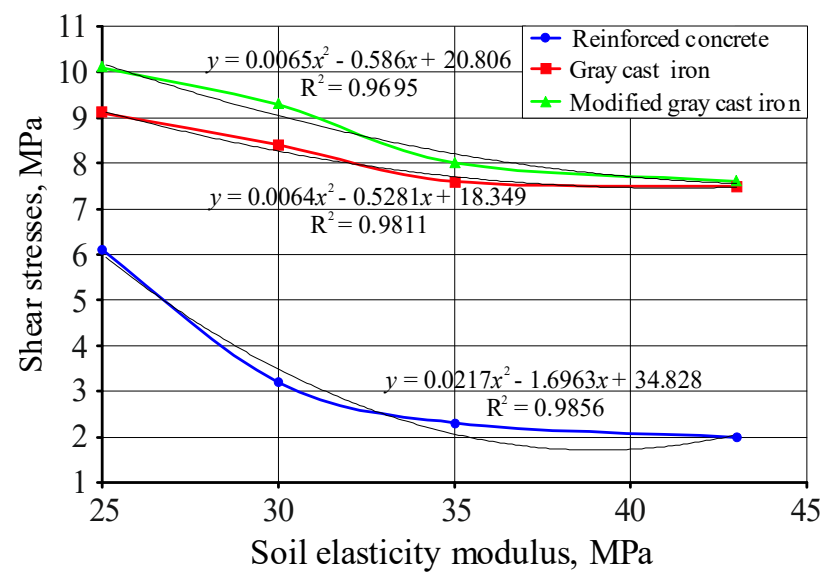

Figure 9. Graph of $T_{x z}$ regularities depending upon sandy soil elasticity modulus for the three frame types

$-T_{x z}$ dependence of sand $E$ is $y=0.0217 x^{2}-$ $-1.6963 x+34.828$.

If the frame is made of gray cast iron tubings, then:

$-N_{x}$ dependence of sandy clay $E$ is $y=0.0144 x^{2}-$ $-1.1828 x+50.738$

$-N_{z}$ dependence of sandy clay $E$ is $y=0.0345 x^{2}-$

$-2.9963 x+129.27$

$-T_{x z}$ dependence of sandy clay $E$ is $y=0.0064 x^{2}-$ $-0.5281 x+18.349$. 
If the frame is made of the modified gray cast iron tubings, then:

$-N_{x}$ dependence of sandy clay $E$ is $y=0.0216 x^{2}-$ $-1.7144 x+61.453$

$-N_{z}$ dependence of sandy clay $E$ is $y=0.036 x^{2}-$ $-3.107 x+132.3$

$-T_{x z}$ dependence of sandy clay $E$ is $y=0.0065 x^{2}-$ $-0.586 x+20.806$.

Standard error of the graphs is $R^{2}$ too being close to 1 confirming their almost functional nature. Consideration of coefficients under $x$ argument and free terms of the listed graphs helps understands that for the $N_{x}, N_{z}$, and $T_{x z}$ graphs of dependence upon soil $E$ for the tubing frames, made of gray cast iron and modified ones, they are similar between corresponding functions when coefficients and free terms for $N_{x}, N_{z}$, and $T_{x z}$ graphs of dependence upon soil $E$ for the tubing frames, made of gray cast iron and reinforced-concrete blocks differ by orders; the fact is not surprising since stiffness of the frames also differs by an order.

Qualitative analysis of the graphs means that maximum stresses within concrete-iron frames, when sandy soil freezes down to $-10^{\circ} \mathrm{C}$, are: $N_{x}=15.2 \mathrm{MPa}$ if normal stresses along $X$ axis (horizontal); $N_{z}=34 \mathrm{MPa}$ if normal stresses along $Z$ axis (vertical); and $T_{x z}=2 \mathrm{MPa}$ if shear stresses within $X Z$ plane.

Maximum stresses within a frame, made of gray cast iron tubings, when sandy soil freezes down to $-10^{\circ} \mathrm{C}$, are: $N_{x}=26.6 \mathrm{MPa}$ if normal stresses along $X$ axis (horizontal); $N_{z}=64.5 \mathrm{MPa}$ if normal stresses along $Z$ axis (vertical); and $T_{x z}=7.5 \mathrm{MPa}$ if shear stresses within $X Z$ plane.

Maximum stresses within a frame, made of modified gray cast iron tubings, when sandy soil freezes down to $-10^{\circ} \mathrm{C}$, are: $N_{x}=27.7 \mathrm{MPa}$ if normal stresses along $X$ axis (horizontal); $N_{z}=65.5 \mathrm{MPa}$ if normal stresses along $Z$ axis (vertical); and $T_{x z}=7.6 \mathrm{MPa}$ if shear stresses within $X Z$ plane.

Unite the obtained regularities into spatial surfaces to have better representativeness and to obtain general pattern of the dependence of a stress state of the multilayer neighbourhood rock mass - frozen soil - hoisting shaft frame system. Construction of such graphs (Figs. 10 - 15) will make it possible to unify the obtained data widening their application area for the frames where values of elasticity modulus $E$ differ from those studied before.

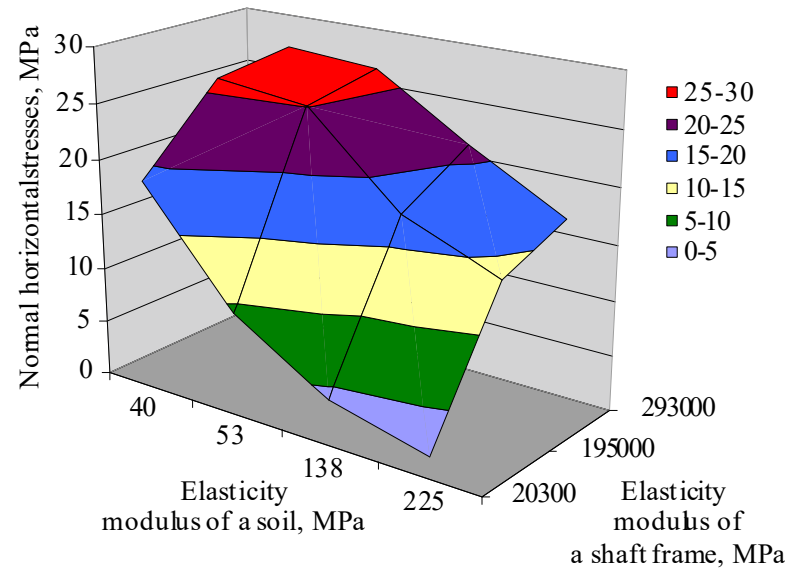

Figure 10. Graph of $N_{x}$ dependence upon sand elasticity modulus and a hoisting shaft frame

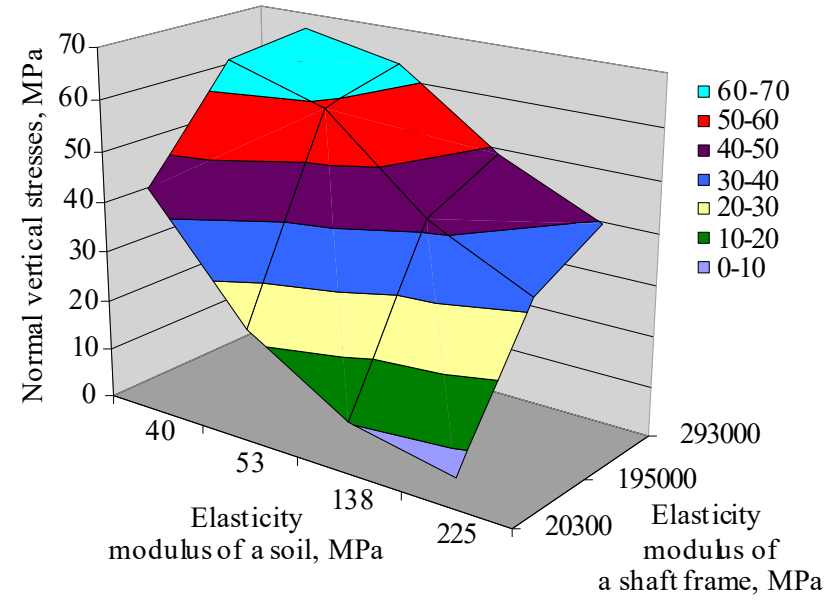

Figure 11. Graph of $N_{z}$ dependence upon sand elasticity modulus and a hoisting shaft frame

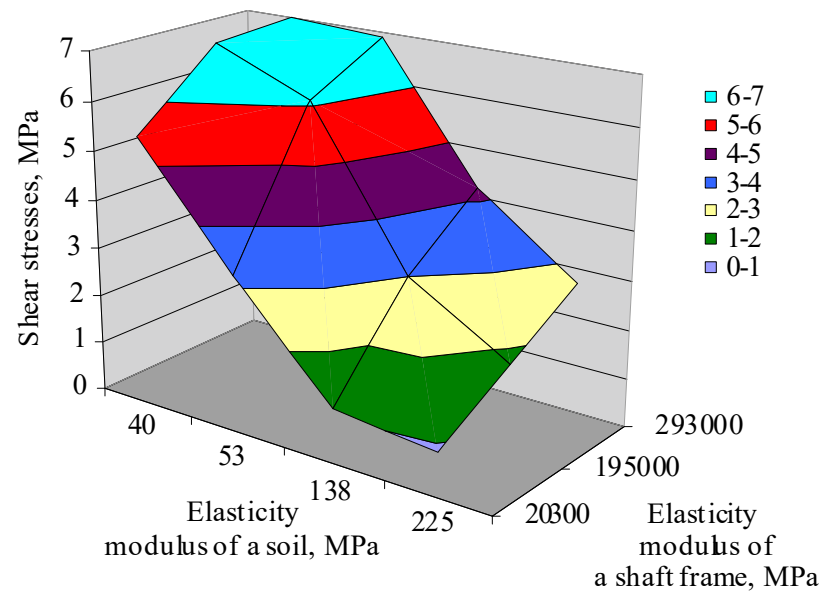

Figure 12. Graph of $T_{x z}$ dependence upon sand elasticity modulus and a hoisting shaft frame

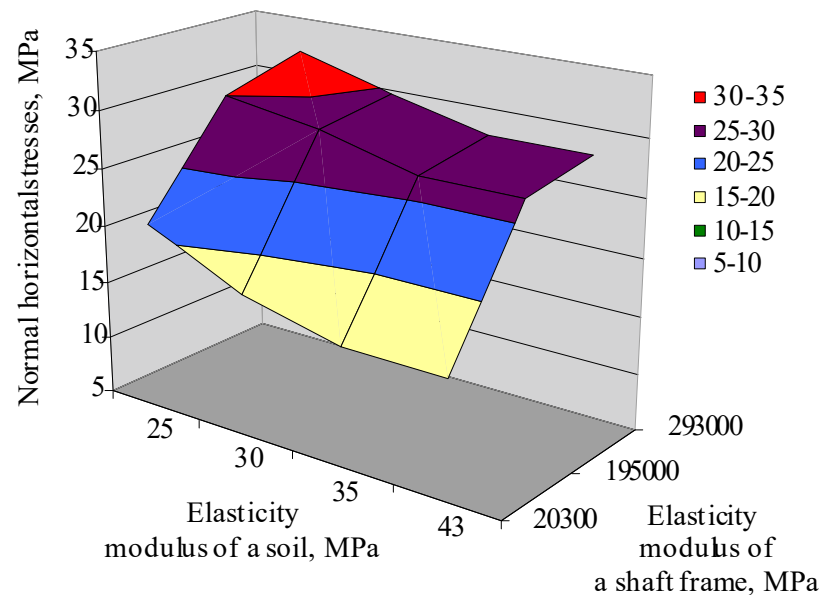

Figure 13. Graph of $N_{x}$ dependence upon sandy clay elasticity modulus and a hoisting shaft frame

The obtained dependences of stress state components of a hoisting shaft upon elasticity modulus of a soil and material are composite spatial surfaces demonstrating representatively stress state of the multilayer neighbourhood rock mass - frozen soil - hoisting shaft frame system. In actual fact, stress state of a frame with the selection of effective parameters can be controlled in such a way. 


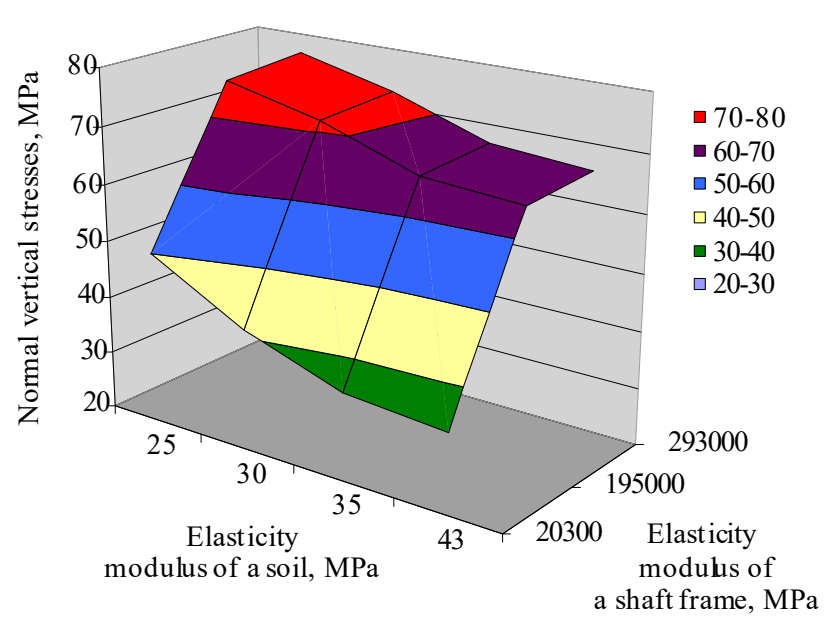

Figure 14. Graph of $N_{z}$ dependence upon sandy clay elasticity modulus and a hoisting shaft frame

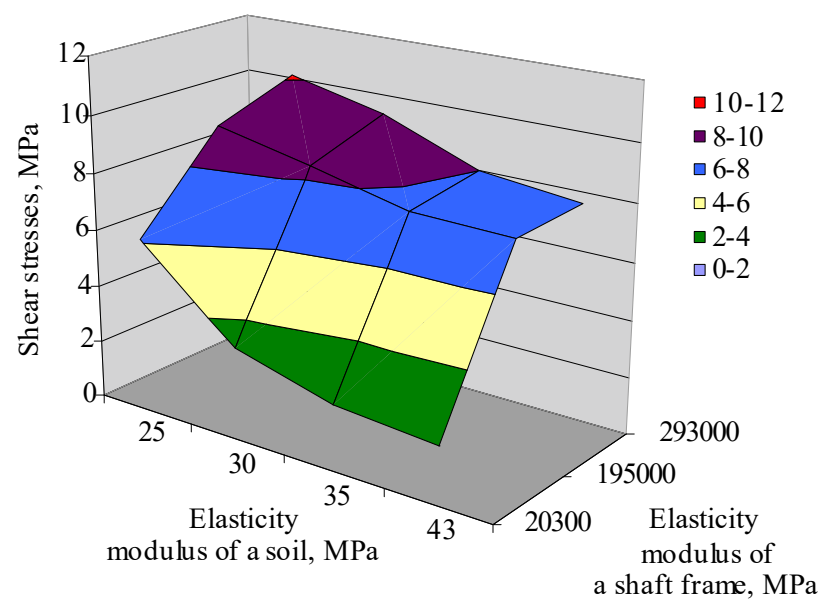

Figure 15. Graph of $T_{x z}$ dependence upon sandy clay elasticity modulus and a hoisting shaft frame

Thermotechnical calculations of ice-soil blocking are done after the analysis of geotechnical and hydrogeological situation concerning location of a hoisting shaft. The calculations involve determination of its parameters as well as properties of soil to be frozen. While predetermining elasticity modulus of the frozen soil, it is required to record its values within the corresponding axis of dependence graph of a stress state certain component. The point is used to line up a straight being parallel to the stress axis. The straight will contact with the surface. A straight to the line, corresponding to a frame elasticity module, should be constructed from the cross point of a straight and the surface; the straight has to be parallel to the soil elasticity modulus axis. While knowing specific value of the property, it is possible to select material for the frame, and determine its thickness. In this context, changes in thickness should also involve inertia of the frame section in turn factoring into changes in the frame elasticity modulus.

In this context, inverse problem should be solved. If one knows a frame thickness, its cross-section inertia, and elasticity modulus, it is necessary to use the graph for following developments. Having the frame elasticity modulus and specific value of the stress component, it is necessary to line up straights from the points, corre- sponding to the values. The straights should be parallel to the stress axis and soil elasticity modulus. After the straights are united by means of perpendiculars, touching spatial surface, the point has to be projected on a frame elasticity modulus - soil elasticity modulus plane and perpendicular has to be constructed to a soil elasticity modulus axis. If elasticity modulus of frozen soil is known, it is quite easy to determine negative temperature for the required strain characteristic.

Hence, both direct and inverse problem can be solved, i.e. a problem concerning selection of a frame geometry in terms of the available values of a frozen soil elasticity modulus, and tests of the rated frame with operational recommendations as for the specific freezing method.

\section{CONCLUSIONS}

Hence, the obtained regularities of the stress state of a multilayer neighbourhood rock mass - frozen soil hoisting shaft frame system help control it, selecting rational geometry and a frame material as well as temperature for a cycle of soil freezing while applying the specific technique.

Plotting of such graphics of a stress state dependence upon a soil elasticity modulus and a hoisting shaft frame in the context of a specific case of underground structure construction will make it possible to develop a soil freezing pattern. Such a rock mechanics pattern will help control a stress state of a hoisting shaft frame while varying temperature mode in the process of construction and monitoring of both erection and additional procedures. That will make it possible to save expenditures while projecting as well as while constructing; besides, a stress state of a multilayer neighbourhood rock mass frozen soil - hoisting shaft frame system will be controlled more consciously.

However, despite the fact that the results are considered as original and practical, it should be noted that the research needs its continuation. That concerns the following: formation of the system stress state is more complicated during unfreezing cycle. In this case, stress state control is topical problem as well since characteristics of rock mass under unfreezing are more negative for a frame to compare with those during freezing cycle. The problem is being solved for a specific freezing method to be applied for the construction of a hoisting shaft in Kyiv subway.

\section{ACKNOWLEDGEMENTS}

The results of the study were obtained in the process of implementing the state-financed research Analytical regularities of a stress-strain state of frame of hoisting shafts while specific operation performing (official registration No. 0117U006810). The authors express thanks to S.M. Likhman, Chief Engineer of Kyivmetrobud PJSC, and M.V. Bilous, Candidate of Science and Director of a Ukrheodezmark being a subsidiary company of Kyivmetrobud PJSC for their counseling as for the specific method of soil freezing and selection of rational designs of a hoisting shaft. 


\section{REFERENCES}

Alzoubi, M.A., Sasmito, A.P., Madiseh, A., \& Hassani, F.P. (2017). Intermittent freezing concept for energy saving in artificial ground freezing systems. Energy Procedia, (142), $3920-3925$ https://doi.org/10.1016/j.egypro.2017.12.297

Andersland, O.B., \& Ladanyi, B. (2003). Frozen ground engineering. London, United Kingdom: John Wiley \& Sons, American Society for Civil Engineers.

Borshchevskiy, S.V., Petrenko, V.D., Tyut'kin, A.L., Antonov, E.B., \& Pleshko, M.S. (2006). Raschet krepi stvola metodom konechnykh elementov. Heotekhnichna Mekhanika, (66), 89-96

Chan, S.S.M. (1985) Structural design considerations for deep mine shafts: Analysis of circular, rectangular, and elliptical openings. Michigan, United States: University of Michigan Library.

Coulthard, M.A. (1999). Applications of numerical modelling in underground mining and construction. Geotechnical and Geological Engineering, 17(3/4), 373-385. https://doi.org/10.1023/a:1008951216602

Donohoe, J.F., Maishman, D., \& Schmall, P.C. (1998). The freezing of soil masses as an aid to engineering construction. Soil Improvement for Big Digs, (81), 149-160.

Dorman, Ya.A. (1981). Spetsialnye sposoby rabot pri stroitel'stve metropolitenov. Moskva: Transport.

Falter, B. (1990). Stability of liners in shaft design. International Journal of Rock Mechanics and Mining Sciences \& Geomechanics Abstracts, 27(2), A124, 169-177. https://doi.org/10.1016/0148-9062(90)95347-4
Falter, B. (1996). Structural analysis of sewer linings. Tunnelling and Underground Space Technology, (11), 27-41. https://doi.org/10.1016/s0886-7798(97)00020-5

Harris, J.S. (1995). Ground freezing in practice. London, United Kingdom: American Society for Civil Engineers.

Hohmann, M. (1997). Soil freezing - the concept of soil water potential. State of the art. Cold Regions Science and Technology, 25(2), 101-110. https://doi.org/10.1016/s0165-232x(96)00019-5

Karpilovskiy, V.S., Kriksunov, E.Z., \& Perel'muter, A.V. (2000). $S C A D$ dlya pol'zovatelya. Moskva: VVP "Kompas".

Levit, V.V., Tyut'kin, A.L., \& Borshchevskiy, S.V. (2007). Matematicheskoe modelirovanie sistemy "stvol - gorizontal'naya vyrabotka" metodom konechnykh elementov. Heotekhnichna Mekhanika, (73), 41-54.

Petrenko, V.I., Petrenko, V.D., \& Tyut'kin, A.L. (2005). Sovremennye tekhnologii stroitel'stva metropolitenov v Ukraine. Kyiv: Nauka i osvita.

Pimentel, E., Anagnostou, G., \& Sres, A. (2007). Modelling of ground freezing in tunnelling. Underground Space - The 4th Dimension of Metropolises, (1), 331-336. https://doi.org/10.1201/noe0415408073.ch56

Yang, W.H., Yang, Z.J., Han, T., Zhang, C., \& Bo, D.-L. (2012) Elastic design theory of frozen soil wall based on interaction between frozen soil wall and surrounding rock. Chinese Journal of Geotechnical Engineering, 34(3), 516-519.

Yang, W.H., Yang, Z.-J., \& Bo, D.-L. (2013). Elastic-plastic design theory of frozen soil wall based on interaction between frozen wall and surrounding rock. Chinese Journal of Geotechnical Engineering, 35(1), 175-180.

\section{УПРАВЛІННЯ НАПРУЖЕНИМ СТАНОМ ОПРАВИ ШАХТНОГО СТОВБУРУ ПРИ СПЕЦАЛЬНОМУ СПОСОБІ ЗАМОРОЖУВАННЯ}

\section{О. Тютькін, В. Петренко, Н. Петросян, В. Мірошник, А. Алхдур}

Мета. Отримання в ході чисельного аналізу закономірностей зміни напруженого стану багатошарової системи “грунт оточуючого масиву - заморожений грунт - оправа шахтного стовбуру” для управління напруженим станом оправи із підбором ефективних параметрів (наприклад, товщини) в залежності від параметрів спеціального способу заморожування.

Методика. Застосовано чисельний аналіз на основі методу скінченних елементів, реалізований на базі професійного комплексу Structure CAD for Windows (SCAD), що дозволив отримати напружений стан оправи шахтного стовбуру із його взаємодією із льодогрунтовим огородженням та грунтом оточуючого масиву.

Результати. Створено модель шахтного стовбура, що побудована на основі реальних геометричних розмірів i результатів лабораторних досліджень. В ході чисельного аналізу із застосуванням SCAD досліджено три типи оправи (залізобетонні блоки, тюбінги з сірого чавуну та тюбінги з модифікованого сірого чавуну), два типи грунтів (пісок та суглинок при температурі $+8^{\circ} \mathrm{C}$ ) при різних температурах заморожування $\left(-2,-6 \mathrm{i}-10^{\circ} \mathrm{C}\right)$. Результати досліджень дозволили відшукати залежності формування напруженого стану багатошарової системи “грунт оточуючого масиву - заморожений грунт - оправа шахтного стовбуру" при варіації властивостей вказаних типів оправи, грунту оточуючого масиву та льодогрунтового огородження. Отримано закономірності компонент напруженого стану від модуля пружності замороженого грунту, що відповідає певній його температурі, та модуля пружності оправи шахтного стовбуру. Дані закономірності пов'язують зміну напружень оправи шахтного стовбуру при спеціальному способі заморожування.

Наукова новизна. Отримані залежності компонент напруженого стану оправи шахтного стовбуру від модулю пружності грунту та матеріалу є складними просторовими поверхнями, що репрезентативно відображають напружений стан багатошарової системи "грунт оточуючого масиву - заморожений грунт - оправа шахтного стовбуру".

Практична значимість. Закономірності напруженого стану, визначені для багатошарової системи "грунт оточуючого масиву - заморожений грунт - оправа шахтного стовбуру", дозволяють управляти компонентами напружень, підбираючи раціональні геометричних параметри та матеріал оправи, або температуру циклу заморожування грунтів при застосуванні цього спеціального способу.

Ключові слова: шахтний стовбур, напружений стан, система "трунт оточуючого масиву - заморожений трунт - оправа шахтного стовбуру”, заморожування трунтів, льодогрунтове огородження, чисельний аналіз 


\section{УПРАВЛЕНИЕ НАПРЯЖЕННЫМ СОСТОЯНИЕМ ОПРАВЫ ШАХТНОГО СТВОЛА ПРИ СПЕЦИАЛЬНОМ СПОСОБЕ ЗАМОРАЖИВАНИЯ}

\section{А. Тютькин, В. Петренко, Н. Петросян, В. Мирошник, А. Алхдур}

Цель. Получение в ходе численного анализа закономерностей изменения напряженного состояния многослойной системы “грунт окружающего массива - замороженный грунт - оправа шахтного ствола" для управления напряженным состоянием оправы с подбором эффективных параметров (например, толщины) в зависимости от параметров специального способа замораживания.

Методика. Применен численный анализ на основе метода конечных элементов, реализованный на базе про-профессионального комплекса Structure CAD for Windows (SCAD), позволивший получить напряженное состояние оправы шахтного ствола с его взаимодействием с льодогрунтовым ограждением и грунтом окружающего массива.

Результаты. Создана модель шахтного ствола, построенная на основе реальных геометрических размеров и результатов лабораторных исследований. В ходе численного анализа с применением SCAD исследованы три типа оправы (железобетонные блоки, тюбинги из серого чугуна и тюбинги из модифицированного серого чугуна), два типа грунтов (песок и суглинок при температуре $+8^{\circ} \mathrm{C}$ ) при различных температурах замораживания $\left(-2,-6\right.$ и $\left.-10^{\circ} \mathrm{C}\right)$. Результаты исследований позволили отыскать зависимости формирования напряженного состояния многослойной системы “грунт окружающего массива - замороженный грунт - оправа шахтного ствола" при вариации свойств указанных типов оправы, грунта окружающей массива и льодогрунтового ограждения. Получены закономерности компонент напряженного состояния от модуля упругости замороженного грунта, что соответствует определенной его температуре, и модуля упругости оправы шахтного ствола. Данные закономерности связывают изменение напряжений оправы шахтного ствола при специальном способе замораживания.

Научная новизна. Полученные зависимости компонент напряженного состояния оправы шахтного ствола от модуля упругости грунта и материала являются сложными пространственными поверхностями, репрезентативно отражающие напряженное состояние многослойной системы “грунт окружающей массива - замороженный грунт - оправа шахтного ствола".

Практическая значимость. Закономерности напряженного состояния, определенные для многослойной системы “грунт окружающей массива - замороженный грунт - оправа шахтного ствола", позволяют управлять компонентами напряжений, подбирая рациональные геометрические параметры и материал оправы, или температуру цикла замораживания грунтов при применении этого специального способа.

Ключевые слова: шахтный ствол, напряженное состояние, система "грунт окружающего массива замороженный грунт - оправа шахтного ствола", замораживание грунтов, льодогрунтовое ограждение, численный анализ

\section{ARTICLE INFO}

Received: 11 April 2018

Accepted: 27 September 2018

Available online: 24 October 2018

\section{ABOUT AUTHORS}

Oleksii Tiutkin, Doctor of Technical Sciences, Chief of the Department of Bridges and Tunnels, Dnipropetrovsk National University of Railway Transport named after Academician V. Lazaryan, 2 Lazaryana St, 49010, Dnipro, Ukraine. E-mail: alexeytutkin@gmail.com

Volodymyr Petrenko, Doctor of Technical Sciences, Professor of the Department of Bridges and Tunnels, Dnipropetrovsk National University of Railway Transport named after Academician V. Lazaryan, 2 Lazaryana St, 49010, Dnipro, Ukraine. E-mail: petrenko.diit@gmail.com

Nataliia Petrosian, Assistant Professor of the Department of Bridges and Tunnels, Dnipropetrovsk National University of Railway Transport named after Academician V. Lazaryan, 2 Lazaryana St, 49010, Dnipro, Ukraine. E-mail: tasha.zirka@gmail.com

Vitalii Miroshnyk, Assistant Professor of the Department of Bridges and Tunnels, Dnipropetrovsk National University of Railway Transport named after Academician V. Lazaryan, 2 Lazaryana St, 49010, Dnipro, Ukraine. E-mail: miroshnikvetal@gmail.com

Ahmad Alkhdour, Doctor of Philosophy, Professor of the Department of Civil Engineering, Al-Balqa`Applied University, Al-Salt 19117, Jordan. E-mail: a.m.alkhdour888@gmail.com 